\title{
Architecture_MPS
}

\section{Branding Stratford: Social Representation and the Re-making of Place}

Antonio Desiderio ${ }^{1}$

How to cite: Desiderio, A. 'Branding Stratford: Social Representation and the Remaking of Place.' Architecture_MPS, 2013, 2(1): 3, pp. 1-15. DOI:

https://doi.org/10.14324/111.444.amps.2013v2i3.001.

Published: 01 March 2013

\section{Peer Review:}

This article has been peer reviewed through the journal's standard Editorial double blind peer review.

\section{Copyright:}

(C) 2013, The Author(s). This is an Open Access article distributed under the terms of the Creative Commons Attribution License (CC-BY) 2.0 https://creativecommons.org/licenses/by/2.0/, which permits re-use, distribution and reproduction in any medium, provided the original author and source are credited • DOI: https://doi.org/10.14324/111.444.amps.2013v2i3.001

\section{Open Access:}

Architecture_MPS is a peer-reviewed open access journal. 


\section{Title: Branding Stratford: Social Representation and the Re-making of Place}

\section{Author: Antonio Desiderio}

Architecture_media_politics_society. vol.2, no.3.

March 2013

Affiliation: University of East London, UK

\section{Abstract:}

As part of the societal world, architecture and urban space do not have any 'objective' quality. They are representations. Their meaning is produced through the negotiation and interaction of individuals, groups and classes. Yet, such 'subjective' meanings do have a 'material' relevance, as they reflect a dialectical process between the functions, forms, ownership and practices of space. They reveal construal and construction: the way in which architectural spaces are represented on the one hand, and the way in which they are physically constructed and used on the other. Nowhere does this become more evident in our current society than in the arguments around urban renewal and regeneration. The Westfield Stratford City is a typical example.

Part of the vast process of the urban regeneration of East London prompted by London 2012 Olympic Games, Westfield is a massive complex of luxury shops, restaurants, bars and five star hotels. It is seen by investors and local and national political authorities as capable of transforming Stratford into a site for shopping, tourism and leisure. It does this in numerous ways, one of which involves reconfiguring the image of the region through the press and media - through visual imagery and linguistic manipulations that promote a neoliberal agenda of gentrification that simultaneously devalue the existent societal structures and communities in the area. This paper offers a Critical Discourse Analysis of the manipulation of Stratford's image by government, business and the media and suggests that the purely financially motivated misrepresentation it reveals, is typical of the urban regeneration ethos at work across the developed world today. 


\title{
Title: Branding Stratford: Social Representation and the Re-making of Place
}

\author{
Author: Antonio Desiderio
}

Architecture_media_politics_society. vol.2, no.3.

March 2013

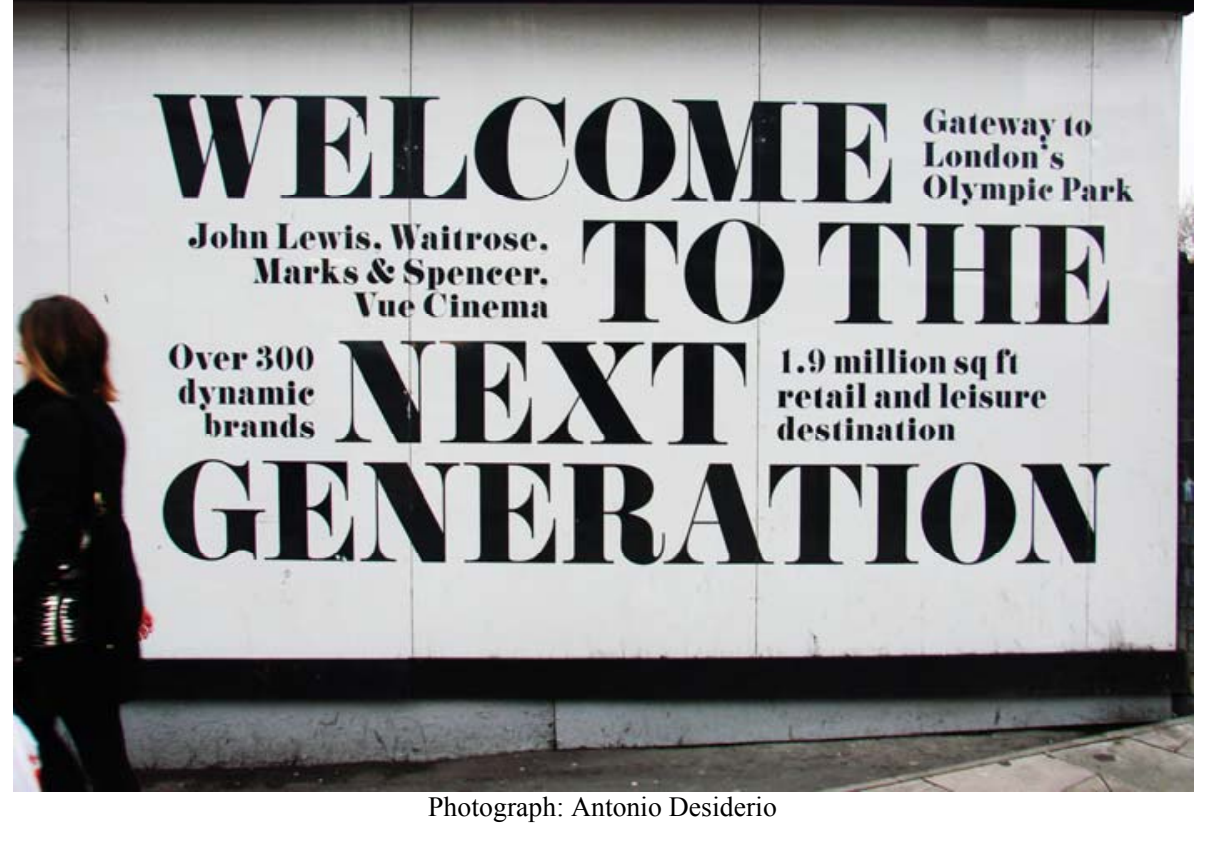

Photograph: Antonio Desiderio

As part of the societal world, architecture and urban space do not have any 'objective' quality. ${ }^{1}$ They are representations. Their meaning is produced through the negotiation and interaction of individuals, groups and classes. Yet, such 'subjective' meanings do have a 'material' relevance, as they reflect a dialectical process between the functions, forms, ownership and practices of space. They reveal construal and construction: the way in which architectural spaces are represented on the one hand, and the way in which they are physically constructed and used on the other. Nowhere does this become more evident in our current society than in the arguments around urban renewal and regeneration. The Westfield Stratford City is a typical example.

Part of the vast process of the urban regeneration of East London prompted by London 2012 Olympic Games, Westfield is a massive complex of luxury shops, restaurants, bars and five star hotels. It is seen by investors and local and national political authorities as capable of transforming Stratford into a site for shopping, tourism and leisure. It does this in numerous ways, one of which involves reconfiguring the 


\section{Amps}

image of the region through the press and media - through visual imagery and linguistic manipulations that promote a neoliberal agenda of gentrification that simultaneously devalue the existent societal structures and communities in the area. This paper offers a Critical Discourse Analysis of the manipulation of Stratford's image by government, business and the media and suggests that the purely financially motivated misrepresentation it reveals, is typical of the urban regeneration ethos at work across the developed world today.

\section{Introduction:}

The issue of place-making through media representations of urban space and architecture has been broadly investigated by architectural historians and critics in a variety of contexts. Mario Carpo for example, investigates the relationship between the availability of printed and reproducible images of the classical orders and the birth of Renaissance architecture in $16^{\text {th }}$ century Europe. ${ }^{2}$ In a more contemporaneous context, Beatriz Colomina highlights the role played by media representations and mass culture in the establishment and promotion of the "International Style" in the United States of the 1930s. ${ }^{3}$ Treading a slightly different path, Jordana Mendelson and Medina Lasansky seek to understand how promotional images and materials have been employed to transform once marginal and economically vulnerable places, such as Havana, Cuba, into commercially viable venues for tourism and leisure. ${ }^{4}$

Anna Klingmann deals with similar ideas in her examination of the experience economy which, transposed to the urban and architectural context, suggests that the dominant representation of the "global city" is a construct of corporate image and brand architecture. ${ }^{5}$ Similarly, Sharon Zukin focuses on what she calls the "symbolic economy" - the complex of "visual artifacts", such as buildings, squares and streets, that frame the image of the city and are used to sell and/or represent cities to both external and internal audiences. ${ }^{6}$ By way of contrast, Naomi Klein stresses the function of language in this branding of cultural identities and places ${ }^{7}$ and, in a sense, echoes aspects of Roland Barthes' analysis of how myth reformulates pre-existing structures of meaning in the context of capitalist societies more generally. ${ }^{8}$

Of more direct relevance to the line of enquiry set out this paper however, is Eric Hobsbawm's analysis of invented traditions. ${ }^{9}$ Central in terms of understanding the processes of narrative construction/reconstruction, Hobsbawn's invented traditions reveal how the past continually gets reformulated in visions of the future. In addition, it helps explain how shopping is transformed into a ritualised practice in contemporary societies and how it thus operates in the formation of place identity. All of these authors and theories, in one way or another, question the dialogue, and thus the discourse, between image on the one hand, and reality on the other - what we are calling in the context of this paper, construal and construction. They thus all offer variations on the notion of Critical Discourse Analysis.

Within the framework of Critical Discourse Analysis, Norman Fairclough suggests that discourse can be interpreted as: (a) an element of the social processes producing meaning; (b) the language of a particular field or practice; and (c) a particular vision of the societal world associated with a particular culturalideological perspective. ${ }^{10}$ Seen in this context, architecture and urban space are part of the social processes forming cultures and identities and are thus easily defined as discourses - physical representations producing specific cultural-ideological meanings. ${ }^{11}$ However, as discourses they are not isolated, but rather form part of, and come from, other social discourses such as those of politics, the 
tourist industry and the real estate business etc.

If we apply the notion of critique, ${ }^{12}$ as understood in Critical Discourse Analysis, to an analysis of architecture, we are faced with an examination of built forms and spaces that seek to understand how they work in conjunction with other multiple discourses. Together, these discourses are seen as reinforcing and reproducing unequal relations of power between individuals, groups and classes in the context of the built environment. If we apply it specifically to the orders of discourse ${ }^{13}$ surrounding the Olympics and the regeneration of Stratford in recent years, it is a methodology that reveals a particular configuration of discourses composed of different genres and styles that include the economic, the political the social and the and mediatic. All played out through different genre formats, these discourses take on nuanced variations of tone and style. They all however, attempt to do the same thing; to create the conditions necessary for the redevelopment and gentrification of Stratford along neoliberal lines.

\section{The Economic Discourse}

The economic discourse of the Olympics and the regeneration of Stratford was, and continues to be, played out through a variety of places, formats and genres; economic analysis papers by government, financial opinion pieces in newspapers and non-governmental reports on the economic impact of the games on the region. In virtually all cases it is presented through texts with a precise syntactic narrative and a clear one-directional grammatical structure. This genre helps present the Games and the "regeneration" of East London as processes independent of any human agency or individual interest. At the same time, it is assertive and confident and presents itself as unbiased and objective. A typical example was the July 2012 report by the Lloyds Banking Group, "The Economic Impact of the London 2012 Olympic and Paralympic Games". ${ }^{14}$

Six issues were used to structure this report: the economic impact of the Games in terms of GDP; the specific effect of the Games on the construction industry; their influence on tourism; their import to small and medium sized enterprises; and the "happiness effect" - defined as the level of consumer expenditure after the Olympics. These purely economic indicators clearly reflect the interests of the authors - and the subjects and financial institutions behind the regeneration of Stratford - and as a result they cannot be lead to what the title suggests: a study of the economic impact of the Games. On the contrary, the report has to be read as a partial and bi-partisan interpretation of the Games and their impact.

In addition to being indicators to only one interpretation of the Games, these assessments are also potentially misleading - GDP as a measure of the quantity of goods and services produced by a country for example, says nothing about the distribution of wealth among the UK population. Further evidence of the report's one-sidedness is evident in the claim that "the construction activity (instigated by the Games) is expected to support the equivalent of 267,000 "years" of employment in the UK economy during the 2005 to 2017 period. ${ }^{15}$ While not making clear that this figure is a statistical ploy that inflates the apparent impact of the Games it simultaneously ignores the negative impact the loss of these inevitably temporary jobs will have once that the short term increase in economic activity instigated by the Games comes to an end. 


\section{Amps}

The document also estimates an increase of 10.8 million tourist visits to the region between 2005 and 2017 and, more generally and specifically, predicts "considerable growth" in commerce as a direct result of the opening of Westfield Stratford City. Once again however, the report offers no consideration of the possible negative consequences of this particular development on local communities in either social or economic terms - neither gentrification nor the impact of the Westfield on small local shops and commercial activities is mentioned. The report's narrative is clearly structured as a one-dimensional cause-effect process that is highly selective with regard to where it casts its eye.

In addition to all of this, the phraseology employed throughout the report locates the Games as the grammatical (and actual) subject of the arguments. As such, the Games, are represented as an autonomous and independent phenomenon - and not as the object of third party capital interests. Talking about the representation of capital in global economies, John Richardson suggests that "capital, as a social relation, cannot have an existence independent of people". ${ }^{16}$ To personalise capital, as in this case, means to firstly; hide the role that real subjects (multinational companies, corporations, entrepreneurs, etc.) play in reinforcing and sustaining capitalism's social structure and power relations, and secondly, to represent capital as a fact of life that cannot be questioned. ${ }^{17}$

To present its arguments as not only objective but also unquestionable, the phraseology of the Lloyds Report then, identifies the Games and/or regeneration as a specific subject seen to be producing specific effects. However, it is also structured through transitive actions - verbs are used in the present tense and the modal will is repeatedly employed. As a result, the independent and innocent subject is presented in direct terms as something with inevitable (positive) consequences. Talking specifically about the report analysed above, Patrick Foley, chief economist at Lloyds Banking Group, writes:

"There have been a catalogue of economic reports on the Games so far, some of which proclaim fantastical benefits; others which have condemned the whole affair as a waste of taxpayer money. But many have been politically-charged, or have told only a part of the story. What's been missing so far is any attempt to take a broad look at the lively impact of the Games, and to examine not only what the Olympic Park development might do for London, but also how the staging of the Games might deliver benefits across the UK and, critically, to small and medium-sized businesses". ${ }^{18}$

In dismissing any alternative document as inaccurate and biased, Foley's critique of reports "which proclaim fantastical benefits" is intended to reinforce the perception of the 'objective' character of the Lloyds' document instigated by its linguistic construction of impartiality, objectivity, inevitability and benefit. In addition however, the Lloyds' Report and its justification, frame an essentially negative view of Stratford in its existing condition that reveals a clearly neoliberal interpretation of modernity. The report states:

“The Games will doubtless (italics mine) help build London's image as a truly modern city. But the bigger impact will be the regeneration of a neglected area of East London [...]"19.

Not only does this social interpretation label Stratford as neglected, poor, and decaying, the modal 'will' and the adverb 'doubtless' again express certainty, and the word 'modern' is framed in purely neoliberal economic terms. Presented as an almost ethical phenomenon - the "truly modern city" of capitalist free- 


\section{Amps}

market economics is portrayed as regenerated and wealthy. ${ }^{20}$ The reference to Stratford as "a neglected area of East London" needs therefore, to be read in opposition to the "modern city" being constructed by the Olympics - the modern urban space of a privatised site for shopping, leisure and tourism that has come to characterise much of today's contemporary architecture and cities. Defined in these terms, the phrase;

"The Games will doubtless help build London's image as a truly modern city. But the bigger impact will be the regeneration of a neglected area of East London",

can be reformulated as:

.... "But the bigger impact on the Olympics will be the redevelopment of Stratford". ${ }^{21}$

To further sustain the image of Stratford as a decaying area, rather than an economic area full of economic potential for private finance and capital re-development, Foley writes:

"The economics are complex, but the bottom line is that in today's economic climate this is unlikely to be an issue" 22 .

The author thus underlines his reinterpretation and representation of the Games as a purely economic matter by linking them with the current economic crisis. This not only narrows the discussion to the knowledge base of a few 'experts' - those implementing and supporting commercially led interventions in Stratford - it reinforces the representation of the Olympics as a necessary step in the recovery of the UK and the London economies.

\section{The Political Discourse}

The economic discourse, with its own configuration of genres and styles, shapes the political discourse. The Olympics, the economic regeneration it will produce and the rebirth of Stratford that will ensue, are again represented as independent - and thus unquestionable processes. However, as the discourse shifts from the economic to the political, a change occurs - emphasis is placed on who must create the conditions for the 'necessary' transformations required by the 'market' and 'capitalism' not the Games themselves. The 'we' of politicians comes to prescribe what 'we', UK society as a whole, must do in order to make the 'modernisation' of Stratford and East London happen.

The Greater London Authority's text, "Games Accelerate the Rebirth of East London" expresses the position of the Mayor of London in this regard and reformulates the concepts of rebirth and regeneration. ${ }^{23}$ The headline is formed as a transitive action whose denoted meaning is that of the Games doing and/or causing the acceleration of East London's "rebirth". The personalisation of this "rebirth" is then reinforced by the verb "to accelerate" which implies the idea of an existing process. As a result, the Games are again presented as an independent entity and the inevitability of their ameliorative benefits is reinforced by being presented as a process already in motion.

With regard to the use of rebirth and regeneration however, the game being played is different. To say 


\section{Amps}

that East London is being regenerated and brought to new life is different from saying that East London is being transformed or redeveloped. 'Transformation' indicates a change which is not necessarily positive and may indeed be negative. By the same token, 'redevelopment' indicates an act of re-construction (to construct anew) and does not necessarily equate directly to improvement.

By contrast, 'rebirth' and 'regeneration' are selected as connoting something positive. They are expected to suggest that the new situation born or generated cannot be anything but 'good' and, by extension, suggest that what existed before cannot be anything but 'bad'. An underlying presentation of Stratford as a run down, neglected and deprived area is thus once more reinforced. The document in facts reports:

"As a result of this massive public and private investment, transforming what has been one of Europe's most impoverished areas for decades, investors from around the world are getting in touch about the multitude of investment opportunities that now exist". ${ }^{24}$

Three issues structure this text's narrative:

1) The transformation of "what has been one of Europe's most impoverished areas for decades"; 2) the creation of a "brand new district" to "generate an unprecedented amount of opportunities" and attract "investors from around the world"; 3) The transformation of Londoners' job prospects.

At work here is a dynamic of opposition of images ('bad' East London vs. 'good' East London) and what linguists call personal deixis. ${ }^{25}$ As Fairclough explains, identities are commonly construed by difference 'we' as not being 'them' (but implying them) - 'me' as not being 'you' (but implying you). In the recontextualisation of the economic discourse in the political arena any opposition between the economic and the political is turned into a coincidence between the two. The 'we' of politicians comes not just to indicate 'we' the government and/or politicians, but 'we' the country.

Accordingly, the 'is' and the 'will' of economic discourse are turned into the 'should', 'ought to' or 'must' of political discourse - which then prescribes what 'we' (the government and the society as a whole) should do in order to answer the challenges faced by capital. The text states:

"Our commitment is to transform job prospects of Londoners"26.

This translates into:

'We politicians' have to create favourable social and economic conditions so as to attract companies that will invest in the area.

In addition to formulating this discourse into one that conflates the government, the people and big business however, this article conflates employment in general with employment by Westfield Stratford City specifically. It reports Sir Robert Wales, Mayor of Newham declaring:

"Our great partnership with Westfield has enabled us to equip local people with the training and expertise they need to get back into work" ${ }^{\text {"27 }}$.

The determinant article employed in this phraseology (the training and expertise) implies the assumption 


\section{Amps}

that these are the training and expertise that people need to get a job in any sector or area of London and the UK. They are, in fact, the training and expertise forming the Westfield's workforce.

All in all, the text reinforces the stereotype of East London as a decaying place, and hence represents an image of its inadequacy to meet the requirements of the market. In doing so, it intends to generate social consensus on the Olympics and the regeneration of Stratford specifically. It is a strategy repeated in numerous other texts that, when analysed do the same thing, one example of which is the "Convergence Action Plan 2011-2015". ${ }^{28}$ In this text, the Mayor of London and the six host boroughs agree that the major legacy of the Games and the regeneration of Stratford is that they will:

“... ensure that over 20 years the scale of disadvantage experienced by Host Borough residents is greatly reduced."

It claims that this will be achieved through:

".... higher education attainment; the an improvement in skills qualifications; increases in the number of economically active adults; a reduction in child poverty; increases in life expectancy; a reduction in housing overcrowding; and a reduction in violent and gang crime." 29

As no mention is made of either the existing potential of the area and its inhabitants or the positive aspects of East London's socio-economic context, this document again represents a one-sided statement that reinforces the stereotype of East London as a decaying place. By repeating the mantra that the Olympics and business offer the only way of improving living standards for East Londoners', and the only method through which the area can be 'modernised', it partakes in a political discourse aimed at generating social consensus for a one dimensional neoliberal economic interpretation of Stratford's future.

\section{The Social and the Media Discourses}

Another discourse through which the neoliberal agenda of a consumerist and gentrified development of Stratford was, and is, played out, is that of the media. In the shift from the economic to the political and into the media discourse however, there is another change in the genre and style of texts and language employed. In this case, the change - which answers the requirements of a different kind medium - is in the dominant social representation of place that is being reinforced. This discourse entails the promotion and presentation of a precise way of acting and interacting in space, as well as a specific identity of both the place and the people who are supposed to inhabit it. It revolves around narratives of shopping, tourism, and living and can be defined as promoting the 'westendisation' of Stratford.

The headline of an article published in The Daily Telegraph on March $2^{\text {nd }}, 2012$ by Graham Ruddick reveals this clearly, "London 2012 Olympics: The Games are coming, so where is the housing boom?"30 In this headline, Ruddick is clear about what the Olympics are about: real estate interests. In a critical discourse analysis of the text, the 'inevitability' of this housing boom is reflected in the adverb "where" that implies not only the possibility, but more specifically the expectation of just such an outcome. It goes 


\section{Amps}

on to say:

"The organisers of London 2012 desperately hope there will be a surge in demand for property in East London. The regeneration of the area, particularly Stratford, was one of the core ambitions behind the bid proposal to the International Olympic Committee in 2005. However, there remains concerns about whether people will actually want to live in the area and whether businesses, who will support the jobs for residents, can be attracted to East London". 31

According to this text, London won the Olympic bid because of the stress it placed on the concepts of 'regeneration' and 'legacy', whose meaning is here redefined in terms of 'westendisation'. Since people already live in Stratford, the doubts about whether people "will actually want to live in the area" is a curious one. In reality, what it actually reflects are doubts about whether West Enders will be willing to move to East London. This representation of Stratford as a place so unattractive that it discourages wealthy people to move there, reinforces the idea that a radical transformation of the social, economic and urban structure of East London is needed. Quoting Yolande Barnes, head of Savills Residential Research, the Ruddick article continues:

“The legacy will effectively be a managed 'landed estate' with an eye on long-term quality that means some localities will have the potential to rival the more prime areas of west London. This should attract newcomers who would otherwise not have considered the location previously".

According to Barnes - the author continues:

“.... an improvement in the local environment would not just attract families to Stratford, but also wealthy overseas investors. If that happens, then the Government and Locog, the London 2012 organising committee, are likely to fulfil their legacy pledge to regenerate East London - even if the housing market is yet to see any real benefits". ${ }^{32}$

Writing from the perspective of the 'social subjects' actually behind the allegedly independent Olympics and the regeneration of Stratford, the Barnes article expresses the vision of a specific group of interests that is construing and imposing its own image upon place. On the ground in Stratford itself, all of this is captured perfectly by the architectural and urban development that is the Westfield Stratford City presented in the media in precisely these gentrified and commercial terms. E-architect, an on-line magazine on architecture, describes Westfield as:

"an innovative fusion of different brands, experiences and formats [that] will grace the threelevel curved mall (with M\&S and John Lewis at either end) and beautifully designed 24-hour lifestyle street that links the Stratford international and regional stations. Art and culture will be integral to the experience - from the striking architecture of individual retail districts and new retail concepts to cultural collaborations, events and installations that will enhance the next generation of retail spaces. Westfield Stratford City is set to transform London's retail landscape and provides the ultimate opportunity for the world's most stimulating and interesting brands". 33

This discourse articulates the concepts of brand, experience and lifestyle through its own specific textual 


\section{Amps}

genre and style. Its genre differs from any academic or specialised text in that it does not provide any information about the structure of the building, the organisation of space, its relation to context or its architectural language. It only provides information on the quantity of stores and the brand of restaurants, bars, cinemas, shops and supermarkets to be found there. It takes on the form of a tourist guide or a glossy magazine.

This is all reflected in its style that is aimed at promoting a product rather than analysing architecture. The text employs a terminology appropriate to the sale of a luxury, cutting-edge, and smart lifestyle and, importantly, promotes the chance to experience it. These stylistic features are repeated in a short film celebrating the opening of the Westfield, "100 Years/Style/East London". In this video piece, the Viral Factory production company presents Westfield a as a place both creating and disseminating fashion. ${ }^{34}$ Through a stream of images representing one hundred years of history as a succession of different styles, it presents fashion as a narrative element that reformulates the history and the identity of East London from 1911 to 2011.

What is at stake in presentations such as these is the re-invention of East London's identity through what we may call, an invented tradition. According to Eric Hobsbawm:

"....invented tradition is taken to mean a set of practices normally governed by overtly or tacitly accepted rules of a ritual or symbolic nature, that seek to inculcate certain values and norms of behaviour by repetition - and which automatically imply continuity with the past. In fact, where possible, it normally attempts to establish continuity with a suitable historic past". 35

Hobsbawm argues that no matter how old a tradition is, the link it creates with the past is always arbitrary and identifies three ways in which such links can be established: 1) by adapting old uses and models to new times and conditions; 2) by employing old materials to construct brand new traditions; 3) by inventing new historical materials for new traditions - because institutions and ideologies can be "so unprecedented that even historical continuity [has] to be invented."

According to this framework, traditions (in contradistinction to customs) are ritualised practices enacted through repetitions that are invariant over time and, as such, are aimed at constructing and strengthening identities. In the case of this creation of a tradition of design, fashion and creativity for Stratford, it is an invented tradition aimed at reinforcing a contemporary image whose goal is commercial gain. It is a social and media based discourse that is a clear manipulation of history.

\section{The Architectural Discourse - Westfield Stratford City}

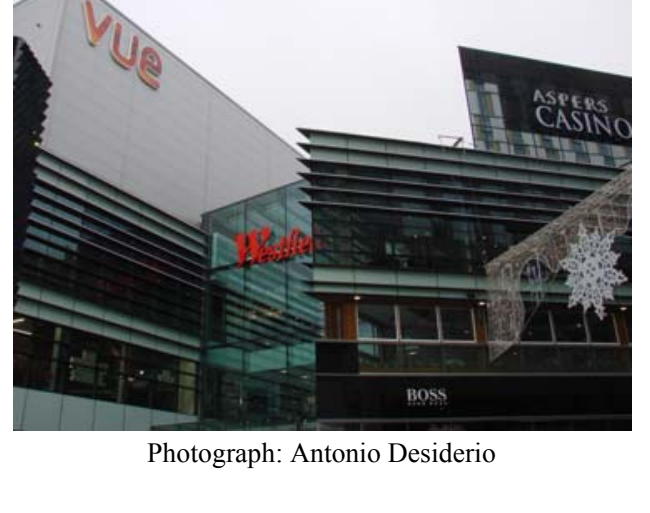




\title{
Amps
}

Through a critical analysis of the economic, political and social/media discourses around the Games then, it is possible to understand who is behind the transformation of Stratford, in whose interest the transformation is taking place, what it is about, and how it reformulates the identity of the place in social, cultural, architectural, urban and functional terms. As a text, that is to say, as semiotic element of a social event, Westfield Stratford City specifically reformulates the discourse of shopping into the media representation of place and, in addition, into a specific spatial and architectural form.

As such, Westfield produces two levels of discourse: construal (its social representation) and construction (its material existence in terms of urban-architectural form, entitlement, practices and functions). In this case, these discourses become so intertwined that they are, at times, seemingly indistinguishable. This is most clearly evident if we consider how the flow of images structuring the narrative of the short film mentioned above, reflects the concept of the continuous space of shopping architecture represented by the complex itself. ${ }^{37}$

Westfield is a flawless and uninterrupted space conceived to maximise the circulation of people and its sales volume. It is a self-referential domain that expresses autonomy through its form and its glazed facades - the glazing prevents any view of the inside for those on the exterior while its form represents a clearly disharmonic intervention in its surroundings - both in urban and specifically architectural terms. Reinforced by its dimensions, which reflect the intention to create a self-contained environment, this autonomy is a perfect example of the Rem Koolhaas attitude to a building's position and relation to its surroundings; 'fuck context'.

The building rejects the pre-existing city and tries instead to create an alternative city: the city of flow (a flow of people, money and goods) - a continuous dimension of shopping and consumerism held together by a complex system of transportation. The mimicking of the language and aesthetics of hi-tec architecture (symbolising the 'modernity' of financial capitalism), the spectacle of lights it offers (expressing the excitement of consumerism), and its stunning display of goods and leisure activities, all create an experiential dimension in which people are offered the chance to enact lifestyle.

All this brings to the fore the issue of the nature of space which Adrian Forty describes when talking about the capacity of architecture to enact a form of dynamic of reflexive perception. He writes:

\begin{abstract}
"Any public building - a railway station, for example - or even any public space - a street can provide the setting for reflexive perception, which allows an individual, through an encounter with the other, to realize his or her own being. But the majority of public buildings in which we both see and are seen belong to someone or some agency, and one's experience of the other is always subordinate to the purposes of the owner. In the railway station, the dominant requirement is to travel; and the form of the building ensures that one does this in the manner, and in the state of mind, that has been ordained by the railway operator. Similarly in the shopping centre, the primary aim of the architectural experience is to ensure that one wants as many of the commodities on sale as possible. In either case, the owners' interests are always dominant, and our experience as individuals is always marginal and alienated; in phenomenological terms, a part of our being is taken from us, but not returned". ${ }^{39}$
\end{abstract}

In line with these arguments, the purpose of Westfield Stratford City must be seen as not providing a free public space, but providing a space that guarantees the mechanism of the selling, buying and consumption of goods - a reality perfectly reflected by its lack of benches or seats which would favour social encounter over shopping. ${ }^{40}$ People cannot just 'stay' in Westfield - they are prompted to buy.

In contrast (in principle at least) to publicly owned spaces, privately owned spaces such as Westfield remove the right to freely express one's civic-political liberties. These liberties are in fact suspended - or 


\section{Amps}

at least strongly regulated by the owner - with activities such as picketing, protesting, skateboarding and taking pictures being banned. However, the banning of these activities is not just enacted by a material system of surveillance and private security, but is also played out through an immaterial, and more subtle and powerful, tool of control - images.

Norman Denzin argues that images enact a self-reflexive dynamic of seeing and being seen that transforms the beholder into the looking-at the looked-at-subject simultaneously. He states:

"From this reflection arose self-ideals and self-appraisal, self-feelings and feelings toward others. [...] Movies created emotional representations of self, sexuality, desire, intimacy, friendship, marriage, work and family. These reflective representations drew upon the ideological structures of everyday life. They created an everyday politics of emotionality and feeling that shaped real, lived, emotional experiences. [...] Real, everyday experiences soon came to be judged - and we may add performed - against their staged, cinematic counterparts. The fans of the movie stars dressed like the stars, made love like the stars and dreamed the dream of the stars". ${ }^{41}$

According to this argument, images and texts construct a narrative of place in which people see themselves reflected - and which they themselves then reflect. In Westfield, such narratives are based on the fetishisation of commodities and consumption through advertising imagery that not only prompts longing for, and identification with, the lifestyle that the Westfield promises, but also indicates the way in which space is to be used - for the parading of gentrified middle class glamour. By saying what space is for, images and texts say who the space belongs to and who is entitled to it.

These images thus help control social behaviour and shape identities by homogenising the uses and practices of the space. They do not express any class, gender and race exclusion and present an image of the space as one that is universally inclusive. Such inclusion however, entails the acceptance of explicit and implicit rules that have not been collectively negotiated, but rather arbitrarily established by the owners on the basis of the people and behaviours they seek to attract and foment. Westfield thus becomes a space for everyone, but not of everyone, as the democratic mechanism of negotiation and discussion about the uses and the practices of space is in fact suspended.

\section{$\underline{\text { Conclusion }}$}

In this case this suspension of a negotiation on the use of space is clearly deeply embedded in the multiple discourses on and around Westfield Stratford City specifically, and the regeneration of Stratford more generally. It was evident in the first strategic arguments for the project from the realm of finance, was threaded through the discourses of politicians charged with creating the conditions for financial transactions and was later manifest in social and media discourses aimed at ensuring the consensus of users and inhabitants. Furthermore, it is manifest in the architecture of the project that becomes a physical discourse that further repeats the logic of contemporary capitalism.

Using a Critical Discourse Analysis it is possible to see how these discourses interact and how they operate through processes of recontextualisation - the economic discourse being recontextualised in the political, the media, the social and eventually, architectural and urban form. These discourses combine in the creation of both the representational and the material dimension of the Olympics and the regeneration of Stratford generally, but also in that of Westfield Stratford City specifically. A Critical Discourse Analysis thus reveals the integrated nature of construal and construction which, in the case of Stratford 


\section{Amps}

meant its re-construal and re-construction as a site for tourism, shopping, leisure and investments.

This reconfiguration of the image of Stratford entails the formulation of a new identity of place, new cultural values, and the formation of new individual and collective identities. Basing itself on neoliberal economic principles and commercial notions of modernity, the multi layered discursive process underlying this new image result in the imposition of a one dimensional capitalist world view on a part of London which was, until recently, seen to be peripheral. It is a perfect example of how architecture and urban spaces can, in contemporary commercial cultures, lose their 'objective' quality and become 'subjective' representations whose meaning is produced through the negotiation and interaction of individuals, groups and classes - in this case primarily those of a corporate elite.

\footnotetext{
${ }^{1}$ In Critical Discourse Analysis, society is seen as complex collection of social practices and/or processes such as architectural design, urban planning, debates, discussions, written and oral texts and images etc. The overall social construct that emerges from these practices is defined as the societal world.

${ }^{2}$ Mario Carpo, Architecture in the Age of Printing: Orality, Writing, Typography and Printed Images in the History of Architectural Theory, (London-Cambridge Mass.: The MIT Press, 2001). Carpo's investigation into the reproduction and dissemination of architectural imagery begins in the middle ages and continues through to the $16^{\text {th }}$ century.

${ }^{3}$ Beatriz Colomina, Privacy and Publicity. Modern Architecture and Mass media (London-Cambridge Mass.: The MIT Press, 1994).

${ }^{4}$ Jordana Mendelson, "From Photographic Fragments to Architectural Illusions at the 1929 Poble Espanyol in Barcelona", in Architecture and Tourism. Perception, Performance and Place, eds. Medina D. Lasansky and Brjan McLaren (Oxford-New York: Berg, 2004), 129-146. Medina D. Lasansky, "Tourist Geographies: Remapping Old Havana", in Architecture and Tourism. Perception, Performance and Place, eds. Lasansky D. M. And McLaren B., 165-188. Jordana Mendelson investigates how architectural photographs of several Spanish cities were employed as models in the construction of a 'typical' Spanish village for the 1929 International Exposition in Barcelona. In a similar way, Medina Lasansky focuses on the role played by glossy journals, illustrated magazines and documentary films in the construction of Habana Vieja as a tourist site during the 1990s.

${ }^{5}$ Anna Klingmann, Brandscapes. Architecture in the Experience Economy (Cambridge Mass.-London: The MIT Press, 2007). According to Klingmann consumer choices are not dependent on the capability of a product to perform a function, but rather on the 'experiential value' attributed to the product. She argues that this is analogous to architecture and urban spaces that, rather than fulfil material requirements, are often expected to enhance specific experiential conditions - conditions primarily created through images that prompt the psychological association of places with a peculiar set of feelings.

${ }^{6}$ Sharon Zukin, The Cultures of Cities (Oxford: Blackwell, 1995).

${ }^{7}$ Naomi Klein, No Logo (London: Fourth Estate, 2010), 182. Klein argues that a relation exists between the "privatization of language and cultural discourse occurring through copyright and trademark bullying and the privatization of public space taking place through the proliferation of superstores, theme-park malls and branded villages".

${ }^{8}$ Roland Barthes, Mythologies (London: Vintage, 1999).

${ }^{9}$ Eric J. Hobsbawm, "Introduction: Invented Traditions", in The Invention of Tradition, eds. Eric. J. Hobsbawm and Terence O. Ranger (Cambridge: Cambridge University Press, 1992), 1-17.
}

\footnotetext{
${ }^{10}$ Norman Fairclough, "A Dialectical Relational Approach to Critical Discourse Analysis in Social Research", in Methods in Critical Discourse Analysis, eds. Ruth Wodak and Michael Meyer (London: SAGE, 2010).

${ }^{11}$ Social practices and/or processes are interpreted as all the forms of acting and interacting taking place in the social world - architectural design, urban planning, debates, discussions, written and oral texts and images etc. Critical Discourse Analysis sees them as reinforcing (or contesting) the social relations of power and dominance and examines them as 'texts' that construct meanings that facilitate social and political domination. By focusing on these practices/processes as 'texts', CDA defines them as discourses themselves. See: Ruth Wodak and Michael Meyer, "Critical Discourse Analysis: History, Agenda, Theory and Methodology", in Methods of Critical Discourse Analysis, eds. Ruth Wodak and Michael Meyer (London: SAGE, 2010), 1-33.

${ }^{12}$ Norman Fairclough, Critical Discourse Analysis. The Critical Study of Language. According to Fairclough and CDA in general, critique is a way of contesting the objectivity of the dominant representations of the processes evident in the societal world through a detailed analysis of how they function.

${ }^{13}$ Orders of discourse constitute configurations of genres, discourses and styles. A discourse, understood as any form of representation, can be enacted in various genres and sub-genres. The genre of writing refers to the underlying structures and syntax employed in a given text that can manifest themselves as sub-genres. For example: a political speech, an academic article or a novel, etc. Style refers to the opinions, fashions, attitudes, aesthetic and cultural values embedded in a given genre - whether that be a written text or a promotional image. See: Norman Fairclough, Critical Discourse Analysis. The Critical Study of Language, (London, Longman: 2010).

14 “The Economic Impact of the London 2012 Olympic and Paralympic Games”, Lloyds Banking Group, accessed July 16, 2012 , http://www.lloydsbankinggroup.com/media/pdfs/lbg/2012/Eco_impact_report.pdf.

15 "The economic Impact of the London 2012 Olympic and Paralympic Games", Lloyds Banking Group, 2012, 2. The report does not explain how "years of employment" are calculated in this case but standard definitions include: a unit of measurement in accountancy based on an ideal amount of work done by one person in a single year, and the amount of work performed by an average worker during one year. Interpreted in
} 
these terms, the number of jobs created is multiplied by the number of years and months that job is created for, thus inflating the quoted figure accordingly. In addition, if a given worker does $30 \%$ overtime (as would be typical in a case like this), the "work performed" factor incorporated into the calculation increases by a factor of $30 \%$. As a result, the use of the "years of employment" definition in this case produces a base quoted figure considerably higher than the actual number of jobs created. It is a clear attempt to use statistics to artificially inflate the apparent impact of the Games.

${ }^{16}$ John Richardson, Analysing Newspapers: An Approach from Critical Discourse Analysis (New York: Palgrave Macmillan, 2007$)$, 56.

${ }^{17}$ Norman and Ruth Wodak, "Critical Discourse Analysis", in Discourses as Social Interaction, ed. Teun A. Van Dijk, Discourse as Social Interaction. Discourse Studies: A Multidisciplinary Introduction, Vol. 2. (London: SAGE, 1997), 258-284.

${ }^{18}$ Patrick Foley, "How the London 2012 Olympics will boost the UK Economy by 16.5bn”, The Telegraph on line, July 6, 2012, http://www.telegraph.co.uk.

${ }^{19} \mathrm{Ibid}$.

${ }^{20}$ Modernity here thus becomes a concept that reflects post-welfare state notions developed in the 1980 s that was paralleled by and, indeed, determined a change in architectural theory and design: the consumerist, market and shopping architecture of Robert Venturi, Frank Gehry and Rem Koolhaas for example, gradually overtaking the previous social models of earlier decades. See: Fredric Jameson, Postmodernism or the Cultural Logic of Late Capitalism (Durham: Duke University Press, 2001). See also: Hal Foster, Recodings: Art, Spectacle, Cultural Politics (New York: The New Press, 1985).

${ }^{21}$ Foley, "How the London 2012 Olympics will boost the UK Economy by $16.5 \mathrm{bn}$ ".

${ }^{22}$ Ibid.

23 "Games Accelerate the Rebirth of East London", Greater London Authority, accessed March 3, 2012, http://www.london.gov.uk/media/press_releases_mayoral/games-accelerate-rebirth-east-london

24 "Games Accelerate the Rebirth of East London".

${ }^{25}$ In linguistics deixis refers to the idea that in order to understand the meaning of words and phrases contextual information are required. Person deixis focuses on the people involved in the speech / writing act concerned. It is relevant here because of the way in which these texts 'personalise' their language while simultaneously drawing in a wider community of people into their arguments.

26 "Games Accelerate the Rebirth of East London".

${ }^{27}$ Ibid.

28 “Convergence Plan Action 2011-2015”, Greater London Authority, accessed May 5, 2012, http://www.london.gov.uk/publication/strategicregeneration-framework-east-london.

29 “Convergence Plan Action 2011-2015”, Greater London Authority, accessed May 5, 2012, http://www.london.gov.uk/publication/strategicregeneration-framework-east-london.

${ }^{30}$ Graham Ruddick, "London 2012 Olympics: The Games are coming, so where is the housing boom?", The Telegraph on-line, March 2, 2012, http://www.telegraph.co.uk/finance/london-olympics-business/9116341/London-2012-Olympics-The-Games-are-coming-so-where-is-thehousing-boom.html

${ }^{31}$ Ibid.

${ }^{32}$ Ibid.

33 "Westfield Stratford City: New London Shopping Centre", E-Architect, accessed November 17, 2012, http://www.earchitect.co.uk/london/westfield_stratford_city_shopping_centre.htm.

34 "100 Years/Style/East London", Viral Factory, accessed July 14, 2012, http://www.youtube.com/watch?v=7JxfgId3XTs.

${ }^{35}$ Eric Hobsbawm, "Introduction: Invented Traditions", 1.

${ }^{36}$ Ibid., 7.

${ }^{37}$ Rem Koolhaas et. Al, Mutations (Barcelona: ACTAR, 2000), 125-128. "Shopping - Rem Koolhaas claims (2000) - is arguably the last remaining form of public activity. Through a battery of increasingly predatory forms, shopping has been able to colonize - even replace - almost every aspect of urban life. Historical towns centers, suburbs, streets, and now train stations, museums, hospitals, schools, the internet, and even the military, are increasingly shaped by the mechanisms and spaces of shopping". The recontextualisation of the discourse of continuity, bigness, movement, circulation from the economical to the architectural produces a specific kind of space, which is characterised by a very specific combination of structural and syntactic elements (genre), and of aesthetic and cultural values (style). The need for the maximum circulation of people into the shopping area; the need for movement to be smooth and for spaces to be seamlessly connected; and the need for an environment freed from the unpredictability of nature, conjoined into the formula: "Comfort + greater willingness to spend increasing amounts of time indoors = greater likelihood to spend". Such formula shapes the continual space of shopping.

${ }^{38}$ Rem Koolhaas, "Bigness or the Problem of the Large", in S, $M, L, X L$, eds. Rem Koolhaas and Bruce Mau (Köln: Benedikt Taschen, 1997), 502.

${ }^{39}$ Adrian Forty, “The Royal Festival Hall - a 'Democratic' Space?”, in The Unknown City. Contesting Architecture and Social Space, eds Iain Borden, Joe Kerr, Jane Rendell (Cambridge, Mass; London: 2001), 207.

${ }^{40}$ There are no benches no seats in the internal alleys of the buildings. In the external alleys and plaza, benches are placed in a way that people's gaze is constantly directed toward shop windows.

${ }^{41}$ Norman Denzin, The Cinematic Society. The Voyeur's Gaze (London: SAGE, 1995), 28-32. 


\section{Bibliography}

Barthes, Roland. Mythologies. London: Vintage, 2009.

Black, David R. and Van Der Westhuizen, Janis. "The Allure of Global Games for 'Semi-Peripheral' Polities and Spaces: a Research Agenda". Third World Quarterly, Vol. 25, No. 7 (2004): 11951214.

Black, David R. and Bezanson Shona. "The Olympic Games, Human Rights and Democratisation: Lessons from Seoul and Implications for Beijing”. Third World Quarterly (2004): 1245-1261.

Carpo, Mario. Architecture in the Age of Printing: Orality, Writing, Typography and Printed Images in the History of Architectural Theory. London-Cambridge Mass.: The MIT Press, 2001

Colomina, Beatrix. Privacy and Publicity. Modern Architecture and Mass Media. London-Cambridge Mass.: The MIT Press, 1994.

Denzin, Norman. The Cinematic Society. The Voyeur's Gaze. London: SAGE, 1995.

E-architect. "Westfield Stratford Cit: New London Shopping Centre”. Accessed November 17, 2012. http://www.e-architect.co.uk/london/westfield_stratford_city_shopping_centre.htm

Fairclough, Norman. "A Dialectical-Relational Approach to Critical Discourse Analysis." In Methods of Critical Discourse Analysis, edited by Ruth Wodak and Michael Meyer, 162-186. London: SAGE, 2010.

Fairclough, Norman. Critical Discourse Analysis. The Critical Study of Language. Harlow: Longman, 2010 .

Fairclough, Norman and Wodak, Ruth. "Critical Discourse Analysis." In Discourse as Social Interaction. Discourse Studies: A Multidisciplinary Introduction, Vol. 2, edited by Teun Van Dijk, 258-284. London: SAGE.

Forty, Adrian. “The Royal Festival Hall - A 'Democratic' Space?.” In The Unknown City. Contesting Architecture and Social Space, edited by Iain Borden, Joe Kerr, Jane Rendell, and Alicia Pivaro, 200-211. Cambridge, Mass.-London: The MIT Press, 2001.

Foster, Hal. Recodings: Art, Spectacle, Cultural Politics. New York: The New Press, 1985.

Greater London Authority. "Games Accelerate Rebirth of East London.” Accessed March 3, 2012. http://www.london.gov.uk/media/press_releases_mayoral/games-accelerate-rebirth-east-london.

Greater London Authority, “Convergence Plan Action 2011-2015.” Accessed May 5, 2012. http://www.london.gov.uk/publication/strategic-regeneration-framework-east-london.

Hobsbawm, Eric J.. "Introduction: Invented Traditions." In The Invention of Tradition, edited by Eric J Hobsbawm and Terence O. Ranger, 1-17. Cambridge: Cambridge University Press, 1992).

Jameson, Fredric. Postmodernism or the Cultural Logic of Late Capitalism. Durham: Duke University Press, 2001.

Klein, Naomi. No Logo. London: Fourth Estate, 2010. 
Klingmann, Anna. Brandscapes. Architecture in the Experience Economy. Cambridge Mass.-London: The MIT press, 2007.

Koolhaas, Rem. "Bigness or the Problem of the Large". In $S, M, L, X L$, edited by Koolhaas, Rem and Mau, Bruce. Köln: Benedikt Taschen, 1997.

Koolhaas, Rem et. al. Mutations. Barcelona: ACTAR, 2000.

Lasansky D. Medina. and McLaren Brjan. Architecture and Tourism. Perception, Performance and Place. Oxford-New York: Berg, 2004

Lasansky, D. Medina. "Tourist Geographies: Remapping Old Havana." In Architecture and Tourism. Perception, Performance and Place, edited by Medina D. Lasansky and Brjan McLaren, 165188. Oxford-New York: Berg, 2004.

Mendelson, Jordana."From Photographic Fragments to Architectural Illusions at the 1929 Poble Espanyol in Barcelona." In Architecture and Tourism. Perception, Performance and Place, edited by Medina D. Lasansky and Brjan McLaren, 129-146. Oxford-New York: Berg, 2004.

Mitchell, Ed. “They're All Gone.” Perspecta, Vol. 34 (2003): 28-39.

Nauright, John. "Global Games: Culture, Political Economy and Sport in the Globalised World of the $21^{\text {st }}$ Century.” Third World Quarterly, Vol. 25, No. 7 (2004): 1325-1336.

Poynter, Gavin and MacRury, Iain. Introduction to Olympic Cities: 2012 and the Remaking of London, by Gavin Poynter and Iain MacRury, xiii-xvi. Farnham: Ashgate, 2009.

Richardson, John. Analysing Newspapers: An Approach from Critical Discourse Analysis. New York: Palgrave Macmillan, 2007.

Roche, Maurice. Mega-Events Modernity. Olympics and Expos in the Growth of Global Culture. London and New York: Routledge, 2000.

Ruddick, Graham. "London 2012 Olympics: The Games are coming, so where is the boom?” The Telegraph, March 2, 2012. http://www.telegraph.co.uk/finance/london-olympicsbusiness/9116341/London-2012-Olympics-The-Games-are-coming-so-where-is-the-housingboom.html.

Traganou, Jilly. "Mobile Architects, Static Ideas: Santiago Calatrava in Athens.” In Travel, Space, Architecture, edited by Jilly Traganou and Miodrag Mitrašinović, 210-229. Farnham UKBurlington USA: Ashgate, 2009.

Viral Factory. “100 Hundred Years Style East London.” Accessed July 14, 2012. http://www.feeldesain.com/100-years-style-east-london-westfield-stratford-city.html

Zukin, Sharon. The Cultures of Cities. Oxford: Blackwell, 1995. 